\title{
STRUKTUR KOMUNITAS TERIPANG (Holothuroidea) DI PERAIRAN PANTAI DESA NAMTABUNG, KECAMATAN SELARU, KABUPATEN KEPULAUAN TANIMBAR
}

\author{
(Community Structure of Sea Cucumber (Holothuroidea) in \\ Coastal Waters of Namtabung Village, Selaru District, Tanimbar Islands Regency)
}

\author{
Maria Matrutty, D. Wakano*, dan S. Suriani \\ Jurusan Biologi Fakultas Matematika dan Ilmu Pengetahuan Alam Universitas Pattimura \\ mariamatrutty09@gmail.com,delly_wakano@yahoo.co.id,sunnyloma@yahoo.com \\ Corresponding author*
}

\begin{abstract}
ABSTRAK: Teripang merupakan hewan tidak bertulang belakang yang banyak dimanfaatkan oleh masyarakat sebagai bahan pangan dan obat-obatan. Tujuan dari penelitian ini adalah menganalisis struktur komunitas teripang (Holothuroidea) di perairan pantai Desa Namtabung Kecamatan Selaru, Kabupaten Kepulauan Tanimbar. Metode yang digunakan untuk pengambilan sampe teripang adalah metode transek linear kuadrat dengan jumlah stasiun pengamatan sebanyak tiga stasiun, sampel teripang yang diperoleh akan diidentifikasi menggunakan buku identifikasi. Hasil penelitian menunjukan terdapat empat spesies teripang dari famili Holothuridea, genus Holothuria dan Bohadschia dengan jenis-jenis yaitu Holothuria scabra, Holothuria edulis, Holothuria atra, dan Bohadschia marmorata. Kepadatan tertinggi dimiliki oleh jenis Holothuria scabra sebesar 0,202 ind $/ \mathrm{m}^{2}$. Kelimpahan relatif tertinggi ditunjukkan oleh Holothuria edulis sebesar 28,12\%. jenis Nilai indeks keanekaragaman sebesar 1,3662 yang artinya keanekaragaman sedang, dan indeks dominansi 0,2533 yang artinya tidak terdapat spesies yang mendominansi. Pola penyebaran relatif berada pada angka $>1$ yang artinya pola sebaran bersifat mengelompok. Indeks nilai penting tertinggi adalah Holothuria scabra dengan nilai 91,07\%. Secara keseluruhan, struktur komunitas teripang di daerah perairan pantai Desa Namtabung berada dalam kategori stabil.
\end{abstract}

Kata kunci: Struktur komunitas, teripang, indeks ekologi, Desa Namtabung, Maluku

ABSTRACT: Sea cucumber is an invertebrate which is widely used by the community as food and medicine. The purpose of this study is to analyze the community structure of sea cucumber (Holothuroidea) in the coastal waters of Namtabung Village, Selaru District, Tanimbar Islands Regency. The used method to collect sea cucumber samples was the linear quadratic transect method with the number of observation stations as many as three stations, the samples of sea cucumbers obtained will be identified using an identification book. The results showed that there were four species of sea cucumber from the Holothuridea family, genus Holothuria and Bohadschia with the types namely Holothuria scabra, Holothuria edulis, Holothuria atra, and Bohadschia marmorata. Holothuria scabra has the highest density of 0.202 ind / $\mathrm{m} 2$. The highest relative abundance was shown by Holothuria edulis at $28.12 \%$. The type of diversity index value is 1.3662 which means moderate diversity, and the dominance index is 0.2533 , which means that there are no dominant species. The relative distribution pattern is at $>1$, which means that the distribution pattern is clustered. The highest index of importance was Holothuria scabra with a value of $91.07 \%$. Overall, the sea cucumber community structure in the coastal waters of Namtabung Village is in the stable category. The highest index of importance was Holothuria scabra with a value of $91.07 \%$. 
Overall, the community structure of sea cucumber in the coastal waters of Namtabung Village is in the stable category.

Keywords: Community structure, sea cucumber, ecological index, Namtabung Village, Maluku

\section{PENDAHULUAN}

Teripang merupakan hewan tidak bertulang belakang, bertubuh lunak atau berduri. Salah satu komoditi hasil perikanan yang memiliki potensi serta banyak dimanfaatkan oleh masyarakat sebagai bahan pangan dan obat-obatan adalah teripang (Suryaningrum, 2008; Kumayanjati, 2020). Selain itu juga teripang memiliki kadar nutrisi yang tinggi dan nilai penting dalam bidang ekonomi maupun ekologi (Lewerissa, 2014). Dalam bidang ekonomi, teripang memiliki nilai jual yang tinggi baik dalam skala lokal maupun internasional. Hal ini disebabkan kandungan zat-zat obat, makanan dari teripang berkhasiat menyembuhkan, serta dari analisa proksimat daging teripang diperoleh komposisi protein $43 \%$, lemak 2\%, kadar air 17\%, mineral $21 \%$ dan kadar abu 7\% (James dalam Darsono, 2007).

Teripang (Holothuroidea) merupakan biota laut yang paling umum dijumpai (Husain, $d k k$., 2017). Hewan ini banyak terdapat di paparan terumbu karang, di pantai berbatu atau lumpur. Teripang tidak hanya dijumpai di perairan dangkal, ada juga yang hidup di laut dalam, bahkan dalam palung yang terdalam pun masih terdapat teripang. Penyebaran teripang sangat luas di beberapa wilayah, mulai dari kedalaman 1 hingga 40 meter. Salah satu perairan yang merupakan wilayah sebaran teripang adalah Provinsi Maluku Louhenapessy, 2013; Nurafni, $d k k$., 2020). Teripang ditemukan di Perairan Maluku sebanyak 15 jenis yang sangat potensial dikembangkan salah satunya adalah teripang pasir (Holothuria scabra) karena selain memiliki nilai jual, juga sumber protein yang cukup tinggi, serta dapat digunakan dalam industri obat-obatan dan kosmetik (Louhenapessy, 2013).

$$
\text { Kabupaten Kepulauan Tanimbar }
$$
merupakan salah satu Kabupaten di Provinsi
Maluku, yang merupakan salah satu kawasan yang kaya akan flora dan fauna terlebihnya pada daerah perairan pantai dengan potensi ekosistem pesisir yang besar dan bernilai ekonomis penting (Reresy, 2016; Mustafa, dkk., 2018). Hal ini disebabkan karena pengaruh topografi dan oseonografinya yang unik. Salah satu perairan di Kabupaten Kepulaun Tanimbar yang memiliki banyak potensi sumberdaya laut yang tinggi adalah Pulau Selaru (Elfemi, 2013, Suyanto\&Pudjianto, 2014).

Pulau Selaru merupakan salah satu pulau di Kabupaten Kepulauan Tanimbar, memiliki perairan yang masih baik untuk tempat hidup berbagai jenis biota laut. Salah satu desa di Pulau Selaru yang memiliki sumberdaya laut melimpah adalah Desa Namtabung. Perairan Desa Namtabung memiliki substrat berpasir yang sangat mendukung bagi habitat teripang sehingga banyak teripang yang hidup di kawasan perairan ini (Tuhumury, $d k k$., 2019). Hal ini disebabkan substrat pasir merupakan substrat yang kaya akan bahan organik untuk kelangsungan kehidupan teripang (Agusta, $d k k$., 2012).

Jumlah teripang yang begitu banyak menyebabkan terjadinya pengambilan teripang baik untuk dijual maupun untuk dikomsumsi sehari-hari, sehingga dikhawatirkan jika pengambilannya terus dilakukan dapat menyebabkan penurunan populasi alami (Darsono, 2007). Menurut Wiadnyana dkk. (2009), mengatakan bahwa banyaknya permintaan pasar ekspor dengan harga yang sangat tinggi telah memacu masyarakat untuk mengeksploitasi teripang secara besar-besaran sehingga terjadi peningkatan produksi teripang secara nasional, hal ini terlihat dengan adanya data peningkatan produksi teripang kering. Permasalahan ini yang melatarbelakangi pentingnya mengetahui tentang potensi teripang di Perairan Pantai Desa Namtabung. Tujuan penelitian ini yaitu menganalisis struktur 
komunitas teripang yang terdapat di perairan pantai Desa Namtabung, Kabupaten Kepulauan Tanimbar.

\section{METODE PENELITIAN}

Penelitian ini dilakukan pada bulan Februari hingga Maret 2020 di perairan pantai Desa Namtabung Kecamatan Selaru Kabupaten Kepulauan Tanimbar. Metode pengambilan teripang menggunakan metode transek linear kuadran untuk mengetahui struktur komunitas teripang. Panjang pantai pada lokasi penelitian yaitu $1500 \mathrm{~m}$ terbagi menjadi tiga stasiun pengamatan. Panjang masing-masing stasiun $500 \mathrm{~m}$ dengan lebar $103 \mathrm{~m}$. Pada tiap stasiun terdapat 10 transek dengan jarak transek $50 \mathrm{~m}$. Terdapat plot pengamatan dengan ukuran plot 1x1 $\mathrm{m}^{2}$ sebanyak 18 plot dengan jarak antar plot $5 \mathrm{~m}$. Proses pengambilan sampel dilakukan pada saat air surut untuk mempermudah pengambilan spesies teripang. Sampel teripang yang telah diperoleh kemudian diidentifikasi menggunakan buku identifikasi menurut Clark\&Rowe (1971). Analisa struktur komunitas teripang di perairan pantai Desa Namtabung digunakan indeksindeks sebagai berikut:

Komposisi jenis (\%) menggambarkan kekayaan spesies yang terdapat di lingkungan perairan. Komposisi jenis teripang dihitung menggunakan rumus (Odum, 1971) sebagai berikut:

Ket:

$$
\text { pi }=\frac{\text { ni }}{\mathrm{N}} \times 100 \%
$$

$\mathrm{Pi}=$ Komposisi jenis ke- $\mathrm{i}$

$\mathrm{ni}=$ Jumlah individu spesies ke-i

$\mathrm{N}=$ Jumlah keseluruhan spesies

Kepadatan adalah jumlah individu persatuan luas area. Untuk menghitung kepadatan digunakan rumus (Junianto, 2013) sebagai berikut:

$$
\mathrm{Ki}=\frac{n i}{A}
$$

Ket:

$\mathrm{Ki}=$ Kepadatan individu jenis ke- $\mathrm{i}$

$\mathrm{ni}=$ Jumlah total individu jenis ke $\mathrm{i}$

$\mathrm{A}=$ Luas total daerah yang di sampling

Untuk menghitung kepadatan relatif, maka digunakan rumus sebagai berikut:
Ket

$$
\mathrm{KRi}=\frac{\mathrm{Ni}}{\sum \mathrm{n}} \times 100 \%
$$

$\mathrm{KRi}=$ Kepadatan relatif suatu jenis ke-i

$\mathrm{Ni}=$ Kepadatan jenis ke-i

$\sum \mathrm{n}=$ jumlah total kepadatan untuk semua jenis

Kelimpahan spesies menunjukan suatu individu spesies tertentu selalu hadir pada petak pengamatan dalam luasan tertentu. Perhitungan dilakukan dengan menggunakan rumus (Odum, 1971) sebagai berikut:

$$
\begin{gathered}
\text { Kelimpahan }\left(\frac{\text { ind }}{m^{2}}\right)=\frac{\text { Jumlah individu suatu spesies }}{\text { Total pengamatan dimana spesies berada }} \\
\text { Kelimpahan relatif }(\%)=\frac{\text { Total kelimpahan suatu spesies }}{\text { Total } \text { kelimpahan semua spesies }} \times 100 \%
\end{gathered}
$$

Frekuensi kehadiran menunjukan banyaknya petak pengamatan dimana suatu spesies ditemukan dalam lulusan tertentu. Untuk menghitung frekuensi kehadiran digunakan rumus (Odum, 1971) sebagai berikut:

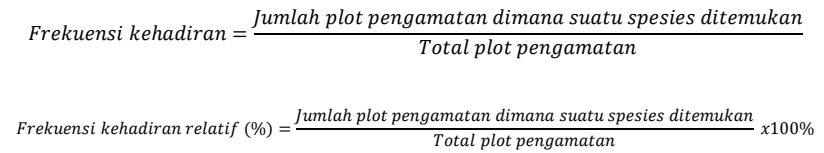

Indeks nilai penting digunakan untuk menghitung dan menduga keseluruhan dari peranan jenis teripang di dalam suatu komunitas. Perhitungan nilai penting menggunakan rumus (Junianto, 2013):

INP $=$ Kepadatan relatif + kelimpahan relatif + Frekuensi relatif

Indeks keanekaragaman jenis teripang berdasarkan Shannon-Winner digunakan untuk mengukur tingkat keteraturan dan ketidakteraturan dalam suatu sistem. indeks keanekaragaman menggunakan rumus (Odum, 1971) sebagai berikut:

Ket:

$$
\mathrm{H}^{\prime}=-\sum \text { pi } \ln \mathrm{Pi}
$$

$\mathrm{H}^{\prime}=$ Indeks keanekaragaman

$\mathrm{Pi}=$ Jumlah spesies ke-i per jumlah total $(\mathrm{ni} / \mathrm{N})$

$\mathrm{Ni}=$ Jumlah individu spesies ke-i

$\mathrm{N}=$ Jumlah total individu

$\mathrm{Ln}=$ logaritma nature 
Jika nilai $\mathrm{H}^{\prime}<1$ maka keragaman spesies rendah. Nilai $H^{\prime} 1 \leq H^{\prime} \leq 3$ artinya keanekaragaman spesies sedang. Nilai $\mathrm{H}^{\prime}>3$ artinya keanekaragaman spesies tinggi.

Indeks dominansi digunakan untuk mengetahui jenis teripang yang paling mendominasi dari jenis lainnya. Dominansi dinyatakan dalam indeks dominansi menurut Simpson (Khouw, 2009).

Ket:

$$
\mathrm{D}=\sum_{1=1}^{s}(\mathrm{pi})^{2}
$$

$\mathrm{Pi}=$ ni $/ \mathrm{N}$

$\mathrm{D}=$ Indeks Dominansi

ni $=$ jumlah individu spesies ke-i

$\mathrm{N}=$ total jumlah individu

Indeks dominansi yang dihasilkan berkisar antara $0-1$. Nilai D mendekati 0 artinya tidak terdapat spesies yang mendominasi spesies lainnya atau struktur komunitas dalam keadaan stabil. Sedangkan nilai D mendekati 1 artinya terdapat spesies yang mendominasi spesies lainnya atau struktur komunitas stabil karena terjadi tekanan ekologis.

Pola distribusi digunakan untuk mengetahui pola penyebaran organisme dalam suatu kawasan tertentu. Rumus indeks penyebaran yaitu :

Ket:

$$
\mathrm{Id}=\mathrm{n} \frac{\Sigma \mathrm{X}^{2}-\mathrm{N}}{\mathrm{N}(\mathrm{N}-1)}
$$

Id = Indeks distribusi

$\mathrm{N}=$ Jumlah total individu dalam total $\mathrm{n}$ plot (ekor)

$\mathrm{n} \quad=$ jumlah plot (unit contoh)

$\Sigma \mathrm{x}^{2}=$ Jumlah individu dikuadrat pada setiap plot

Dengan kriteria pengujian:

Id $=1$, pola distribusi bersifat acak

Id $<1$, pola distribusi bersifat seragam

Id $>1$, pola distribusi bersifat mengelompok

\section{HASIL DAN PEMBAHASAN}

\section{Komposisi Teripang}

Hasil penelitian menunjukan bahwa terdapat 4 spesies teripang dari family Holothuroidea yaitu Holothuria scabra, Holothuria edulis, Holothuria atra, Bohadschia marmorata (Gambar 1). Berdasarkan hasil

\section{DOI: $\underline{\text { https://doi.org/10.30598/TRITONvol17issue1page10-17 }}$}

penelitian presentase komposisi jenis teripang pada ketiga stasiun penelitian menunjukan bahwa persentase tertinggi adalah $32,25 \%$ untuk jenis Holothuria scabra. Holothuria scabra memiliki komposisi tertinggi karena didukung oleh faktor lingkungan. Habitat teripang di lokasi pengamatan yaitu substrat berpasir, pasir berlumpur ditambah pecahan karang mati serta ada juga yang ditumbuhi lamun. Parameter kualitas perairan seperti salinitas sebesar 32,22 ppt, pH 7,82 dan suhu $30,02^{\circ} \mathrm{C}$. Menurut Martoyo, $d k k$. (2007), suhu perairan yang cocok untuk pertumbuhan teripang adalah $24-30^{\circ} \mathrm{C}$. Salinitas yang cocok untuk pertumbuhan teripang berkisar antara 28-32 ppt, sedangkan $\mathrm{pH}$ berkisar antara 6.5-8.5. Konsumsi oksigen terlarut yang optimal bagi teripang pasir sepertinya halnya kebutuhan oksigen di perairan untuk organisme yaitu $>5 \mathrm{mg} / \mathrm{ltr}$. Hal ini membuktikan bahwa perairan pantai Desa Namtabung masih tergolong baik untuk pertumbuhan teripang.

\section{Kepadatan Teripang}

Kepadatan teripang yang ditemukan di perairan Desa Namtabung adalah berkisar antara $0,126 \mathrm{ind} / \mathrm{m}^{2}-0,202 \mathrm{ind} / \mathrm{m}^{2}$ (Tabel 1). Kepadatan tertinggi ditemukan pada jenis Holothuria scabra, kemudian diikuti oleh spesies Holothuria edulis, Halothuria atra, dan Bohadschia marmorata. Tingginya kepadatan teripang pada suatu daerah disebabkan oleh beberapa faktor diantaranya pengaruh suhu, salinitas, dan $\mathrm{pH}$ yang optimum untuk organisme tersebut dapat hidup dan berkembang. Selain itu habitat hidup yang sesuai dapat membuat organisme teripang memperoleh makanan sekaligus bersembunyi dari ancaman predator (Yuniarti, 2012). Habitat karang ataupun pecahan karang dapat digunakan teripang sebagai tempat perlindungan sekaligus mencari makan yang potensial. Nirwana, $d k k$. (2016) menyebutkan bahwa selain dari pasir bercampur rumput laut, pecahan karang atau daerah dekat karang digunakan juga sebagai tempat persembunyian teripang. Umumnya teripang menyukai tipe substrat berpasir seperti jenis-jenis teripang yang ditemukan pada lokasi penelitian ini. Selanjutnya dikatakan pula bahwa pemilihan substrat disesuaikan dengan 
kebiasaan individu untuk mencari makan. Selain faktor ekologis, faktor sosial berupa aktivitas pengambilan teripang oleh masyarakat juga turut mempengaruhi kepadatan teripang. Pengambilan teripang dengan merusak habitatnya dapat merusak ekosistem teripang sekaligus mengurangi jumlah teripang di alam.

Jenis Holothuria scabra, merupakan spesies yang mudah beradaptasi pada substrat berpasir, pasir berlumpur dan substrat yang ditumbuhi lamun. Holothuria scabra merupakan teripang yang hidup pada perairan jernih dan relatif tenang yang pada umumnya memiliki habitat yang spesifik, seperti hidup di daerah berpasir, daerah berbatu di kedalaman 1-40 meter ataupun ditemukan di perairan dangkal yang banyak ditumbuhi rumput laut (Saputra, 2001). Kemampuan beradaptasi yang baik dengan membenamkan dirinya di bawah dasar pasir/karang pasir menjadikan spesies ini mampu memperthankan diri dari gangguan atau ancaman.

Teripang hitam (Holothuria edulis) merupakan urutan kedua yang banyak ditemukan pada ketiga stasiun. Spesies ini banyak ditemukan pada dasar substrat pasir, lumpur pasir maupun lingkungan terumbu.
Keempat jenis teripang yang ditemukan pada lokasi penelitian hidup pada habitat berbeda. Untuk Holothuria edulis dan Holothuria atra memiliki habitat di daerah bersubstrat pasir kasar, sedangkan Holothuria scabra sangat banyak ditemukan pada substrat pasir halus dan ditumbuhi lamun. Habitat dan cara makan berkaitan erat dengan banyaknya Holothuria edulis, diduga jenis teripang ini dapat ditemukan dengan jumlah yang cukup banyak, disebakan substrat pada lokasi penelitian adalah salah satu faktor yang mendukung keberadaan jenis teripang ini. Habitat dengan substrat pasir bercampur patahan karang mati sangat mendukung untuk kelangsungan kehidupan jenis Holothuria edulis (Martoyo, dkk., 2007).

\section{Kelimpahan Teripang}

Kelimpahan relatif teripang yang paling tinggi ditunjukan oleh Holothuria edulis sebanyak 95 individu dengan kelimpahan relatif sebesar $28,12 \%$ (Tabel 2), sedangkan kelimpahan terendah yaitu jenis Holothuria scabra. Rendahnya kelimpahan teripang jenis Holothuria scabra disebabkan oleh kehadiran individu di lokasi yang jarang atau tidak merata pada setiap petak pengamatan.
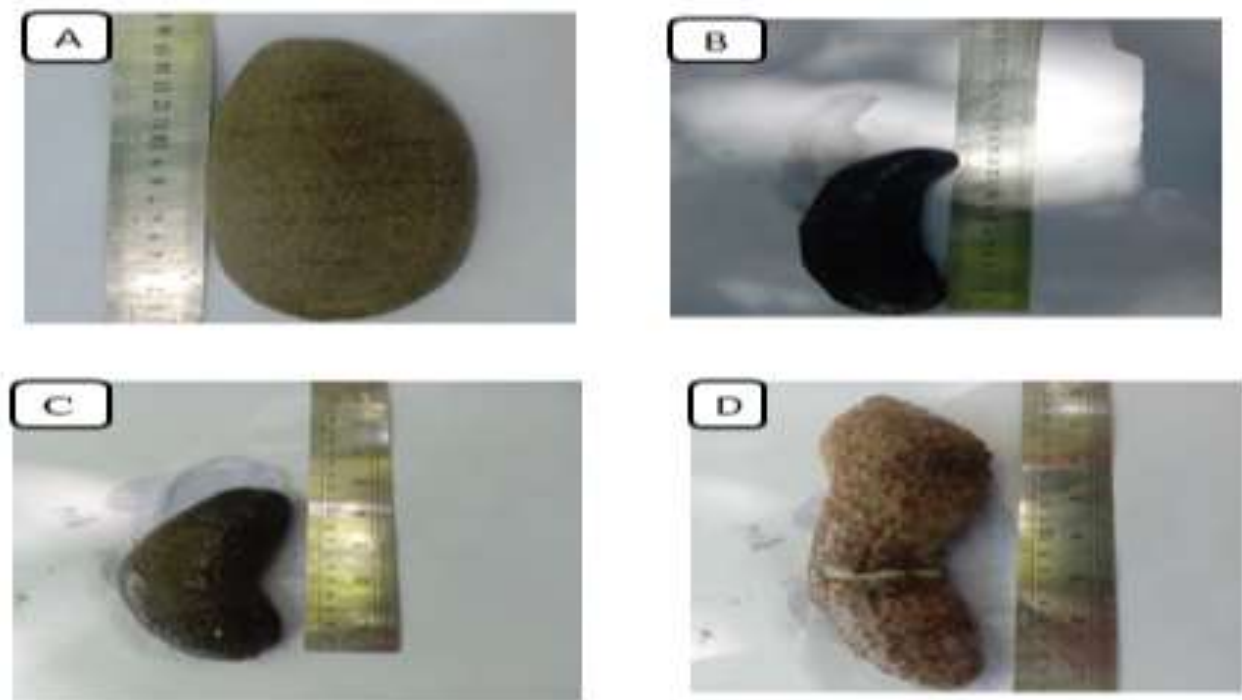

Gambar 1. Jenis-jenis teripang yang ditemukan di perairan pantai Desa Namtabung

Ket: Holothuria scabra (A), Holothuria edulis (B), Holothuria atra (C), Bohadschia marmorata (D) 
Tabel 1. Kepadatan dan kepadatan relatif teripang di perairan Desa Namtabung

\begin{tabular}{ccccc}
\hline No & Spesies & Ki & $\mathbf{2 K}$ & KRi (\%) \\
\hline 1 & Holothuria scabra & 0,202 & & 32,32 \\
2 & Holothuria edulis & 0,159 & 0,625 & 25,44 \\
3 & Holothuria atra & 0,138 & & 22,08 \\
4 & Bohadschia marmorata & 0,126 & & 20,16 \\
& TOTAL & & $\mathbf{1 0 0 . 0 0}$ \\
\hline
\end{tabular}

Berdasarkan hasil penelitian Lewerissa (2014) di Desa Porto Pulau Saparua, teripang jenis nis Holothuria edulis memiliki kepadatan serta frekuensi kehadiran yang cukup tinggi masing-masing yaitu sebesar $0,0069 \mathrm{ind} / \mathrm{m}^{2}$ dan 0,1488 . Ditemukan pula bahwa spesies ini juga mendominasi perairan tersebut dibandingkan dengan spesies lainnya.

\section{Keanekaragaman dan Dominansi Teripang}

Berdasarkan hasil penelitian menunjukan bahwa keanekaragaman teripang pada Perairan Desa Namtabung dalam kategori sedang dengan indeks keanekaragaman 1,3662. Nilai indeks keragaman spesies teripang (H') di Negeri Porto sebesar 1.29 (Lewerissa, 2014). Hal ini disebabkan karena adanya spesies tertentu yang ditemukan dalam jumlah yang lebih banyak jika dibandingkan dengan spesies-spesies yang lain serta adanya tingkat pemanfaatan sumberdaya teripang yang tinggi oleh masyarakat. Indeks keanekaragaman yang sedang mengandung arti tidak ada kompetisi antar jenis teripang di semua titik lokasi penelitian. Adanya ketersediaan makanan yang cukup dan kondisi lingkungan yang mendukung diduga sebagai alasan rendahnya kompetisi baik itu ruang maupun makanan di lokasi penelitian (Nirwana, $d k k ., 2016)$. Nilai dominansi sebesar 0,2533 artinya mendekati angka 0 sehingga dapat dikatakan bahwa tidak ada spesies yang mendominasi.

\section{Distribusi Teripang}

Hasil penelitian menunjukkan sebaran teripang pada perairan Desa Namtabung relatif mengelompok (Tabel 3). Sebaran teripang dari tiga jenis yaitu Holothuria scabra, Holothuria edulis dan Holothuria atra pada ketiga stasiun menunjukkan terjadi pola penyebaran secara mengelompok, sedangkan pada jenis Bohadschia marmorata pola penyebarannya seragam. Pola penyebaran mengelompok yang terjadi pada ketiga spesies diakibatkan spesies tersebut ditemukan cenderung membentuk kelompok dan jarang ditemukan sendiri secara terpisah. Menurut Nirwana, $d k k$. (2016) menyatakan bahwa pola sebaran secara mengelompok disebabkan adanya pengaruh parameter lingkungan tertentu sehingga jenis teripang dapat beradaptasi dengan kondisi tersebut. Selain itu, pola penyebaran mengelompok disebabkan oleh adanya hewan lain sebagai predator. Martoyo, dkk. (2007) bahwa pola penyebaran mengelompok disebabkan oleh adanya hewan lain sebagai predator sehingga teripang ditemukan hidup mengelompok dengan tujuan saling melindungi. Pola penyebaran seragam yang terjadi pada jenis Bohadschia marmorata diduga akibat rendahnya kemampuan adaptasi dalam habitat, sehingga jenis teripang ini hanya ditemukan pada tempat tertentu dan jarang hidup bersamaan dengan jenis lainnya.

\section{Indeks Nilai Penting}

Indeks nilai penting (INP) tertinggi ditunjukkan oleh spesies Holothuria scabra sebesar 91,07\%, sedangkan indeks nilai penting terendah yaitu jenis Bohadschia marmorata. Menurut Wijayanti (2007), bahwa spesies dengan indeks nilai penting tertinggi menunjukan bahwa spesies tersebut hadir dengan jumlah yang cukup banyak, sedangkan spesies dengan indeks nilai penting terendah merupakan spesies yang hadir dengan jumlah yang relatif sedikit. Semakin tinggi indeks nilai penting, maka semakin tinggi pula peran jenis tersebut dalam komunitasnya. 
Tabel 2. Kelimpahan dan kelimpahan relatif teripang di perairan Desa Namtabung

\begin{tabular}{llccc}
\hline No & \multicolumn{1}{c}{ Spesies } & $\begin{array}{c}\text { Total kelimpahan } \\
\text { suatu spesies }\end{array}$ & $\begin{array}{c}\text { Total kelimpahan } \\
\text { semua spesies }\end{array}$ & $\begin{array}{c}\text { KLRi } \\
(\mathbf{\%})\end{array}$ \\
\hline 1 & Holothuria scabra & 1,348 & & 20,35 \\
2 & Holothuria edulis & 1,863 & & 28,12 \\
3 & Holothuria atra & 1,708 & 6,624 & 25,79 \\
4 & Bohadschia & 1,705 & & 25,74 \\
& marmorata & & & $\mathbf{1 0 0 . 0 0}$ \\
\hline
\end{tabular}

Tabel 3. Nilai perhitungan pola penyebaran teripang pada perairan pantai Desa Namtabung

\begin{tabular}{lcccccccccc}
\hline \multicolumn{1}{|c}{$\begin{array}{c}\text { Stasiun } \\
\text { Spesies }\end{array}$} & $\mathbf{1}$ & $\mathbf{2}$ & $\mathbf{3}$ & $\mathbf{N}$ & $\mathbf{N}$ & $\mathbf{\Sigma} \mathbf{X}^{\mathbf{2}}$ & $\mathbf{\Sigma} \mathbf{X}^{\mathbf{2}} \mathbf{- N}$ & $\mathbf{N}(\mathbf{N}-\mathbf{1})$ & $\mathbf{I d}$ & $\begin{array}{l}\text { Pola } \\
\text { penyebaran }\end{array}$ \\
\hline $\begin{array}{l}\text { Holothuria } \\
\text { scabra }\end{array}$ & 40 & 37 & 43 & 89 & 120 & 478 & 358 & 14,280 & $\mathbf{2 , 2 2 5}$ & mengelompok \\
$\begin{array}{l}\text { Holothuria } \\
\text { edulis }\end{array}$ & 28 & 33 & 34 & 51 & 95 & 297 & 202 & 8,930 & $\mathbf{1 , 1 2 2}$ & mengelompok \\
$\begin{array}{l}\text { Holothuria } \\
\text { atra }\end{array}$ & 25 & 30 & 27 & 48 & 82 & 223 & 141 & 6,642 & $\mathbf{1 , 0 0 8}$ & mengelompok \\
$\begin{array}{l}\text { Bohadschia } \\
\text { marmorata }\end{array}$ & 22 & 29 & 24 & 44 & 75 & 201 & 126 & 5,550 & $\mathbf{0 , 9 6 8}$ & seragam \\
\hline
\end{tabular}

\section{KESIMPULAN}

Berdasarkan hasil penelitian yang dilakukan maka dapat disimpulkan bahwa ditemukan empat spesies teripang, dengan keanekaragaman spesies sedang, dan tidak terdapat spesies yang mendominansi. Pola penyebaran teripang relatif mengelompok dan jenis Holothuria scabra memiliki indeks nilai penting tertinggi. Hal ini menunjukan bahwa struktur komunitas teripang di daerah perairan pantai Desa Namtabung berada dalam kategori stabil.

\section{DAFTAR PUSTAKA}

Agusta, Q. R., Sulardiono B, Rudiyanti S. 2012. Kebiasaan makan teripang (Echinodermata: Holothuridae di perairan pantai Pulau Pramuka, Kepulauan Seribu. Journal Management Aquaitic Resources 1 (1):1-8.

Clark, A.M. dan F.W.E. Rowe.1971. Monograph of Shallow Water Indo West Pacific Echinoderms. Trustees of the British Museum (Nat.Hist), London: 238 hal
Darsono, P. 2007. Teripang (Holothuridae): Kekayaan Alam Dalam Keragaman Biota Laut. Oseana (2):1-10.

Elfemi, N., 2013. Sasi, Kearifan Lokal Dalam Pengelolaan Sumberdaya Laut (Kasus Masyarakat Suku Tanimbar di Desa Adaut, Kecamatan Selaru, Kabupaten Maluku Tenggara Barat). Jurnal Pelangi 6 (1): 23-30.

Husain, G., J.F.W.S. Tamanampo, G.D. Manu. 2017. Struktur Komunitas Teripang (Holothuroidea) Pantai Pulau Nyaregilaguramangofa Kec. Jailolo Selatan Kab. Halmahera Barat Maluku Utara. Jurnal Ilmiah Platax 5(2): 177-188.

Junianto, D. 2013. Studi Ekologi Teripang (Holothuroidea) di Perairan Desa Pengudang Kabupaten Bintan. Skripsi. Universitas Maritim Raja Ali Haji, Tanjungpinang.

Khouw, A. S. 2009. Metode dan Analisa Kuantitatif Dalam Bioekologi Laut. Diterbitkan oleh Pusat Pembelajaran dan Pengembangan Pesisir dan Laut. Dicetak Atas Kerjasama Dengan Direktorat Jendral Kelautan, Pesisir dan Pulau-Pulau Kecil (KP3K) Departemen Kelautan dan Perikanan RI.

Kumayanjati, B. 2020. Teripang Sebagai Salah Satu Sumber Kolagen. Oseana 45(1): 17-27. 
Martoyo, J., A. Nugroho, T. Winanto. 2007. Budidaya Teripang. Penebar Swadaya. Jakarta. 76 hal.

Mustafa, A.A., Tarunamulia, Hasawi, I. N. Radiarta. 2018. Evaluasi Kesesuaian Perairan Untuk Budidaya Ikan Dalam Keramba Jaring Apung di Kabupaten Maluku Tenggara Barat Provinsi Maluku. Jurnal Riset Akuakultur 13(3): 277-287.

Lewerissa, Y.A. 2014. Studi Ekologi Sumberdaya Teripang di Negeri Porto Pulau Saparua Maluku Tengah. Biopendix 1(1): 32-42.

Louhenapessy. D. G. 2013. Pengaruh Substrat Berbeda Terhadap Pertumbuhan Teripang Pasir (Holothuria Scabra). TRITON: Jurnal Manajemen Sumberdaya Perairan 9(1): 2632.

Nirwana, E., B. Sadarun, L. O. A. Afu. 2016. Studi Struktur Komunitas Teripang Berdasarkan Kondisi Substrat di Perairan Desa Sawapudo Kabupaten Konawe. Sapa Laut 1(1): 17-23.

Nurafni, S. H. Muhammad, N.S. Kurung. 2020. Pola Sebaran dan Indeks Ekologi Teripang di Perairan Army Dock Desa Pandanga Kabupaten Pulau Morotai. Aurelia Journal 1(2): 121-128.

Odum, E. P. 1971. Fundamental of Ecology. 3 Eds. W. B. Saunders Company, Philadelphia. 574 p.

Satria, G.G.A, Sulardiono, B., dan Purwanti, F. 2014. Kelimpahan JenisTeripang Di Perairan Terbuka dan Tertutup Pulau Panjang Jepara, Jawa Tengah. Management of Aquatic
Resources Journal (MAQUARES) 3(1): 108115.

Saputra. D. A. 2001. Struktur Komunitas Teripang Holothuroidea Di PerairanPantai Pulau Pramuka dan Pulau Tikus, Kepulauan Seribu Skripsi. Fakultas Perikanan dan Ilmu Kelautan. Institut Pertanian Bogor.

Suryaningrum, T.D. 2008. Teripang: Potensinya Sebagai Bahan Nutraceutical dan Teknologi Pengolahannya. Squalen 3(2): 63-69.

Suyanto \& B. Pudjianto. 2014. Kesejahteraan Komunitas di Desa Adaut, Kecamatan Selaru, Provinsi Maluku. INFORMASI 19(2): 107121.

Tuhumury, L., S. Suriani, D. Wakano. 2019. Inventarisasi Teripang (Holothuroidea) di Desa Namtabung Provinsi Maluku. Rumphius Pattimura Biological Journal 1(2): 41-46.

Wijayanti M. 2007. Kajian Kualitas Perairan Di Pantai Kota Bandar Lampung Berdasarkan Komunitas Hewan Makrobenthos. Tesis. Universitas Diponegoro. Semarang.

Wiadnyana, N.N., Puspasari, R., Thomas, R. 2009. Status Sumberdaya dan Perikanan Teripang di Indonesia. Jakarta. Jurnal Kebijakan Perikanan Indonesia 1(1): 45-60.

Yuniarti, N. 2012. Keanekaragaman dan Distribusi Bivalvia dan Gastropoda (Moluska) di Pesisir Glayem Juntinyuat, Indramayu, Jawa Barat. Skripsi. Departemen Biologi Fakultas Matematika dan Ilmu Pengetahuan Alam. Institut Pertanian Bogor. Bogor. 